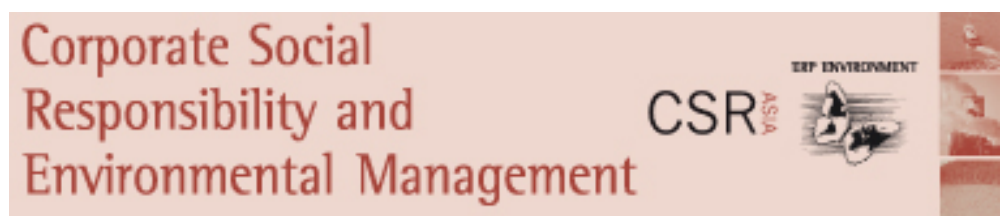

\title{
Do income taxes affect corporate social responsibility? Evidence from European listed companies
}

\begin{tabular}{|r|l|}
\hline Journal: & Corporate Social Responsibility and Environmental Management \\
\hline Manuscript ID & CSR-19-0222.R1 \\
\hline Wiley - Manuscript type: & Research Article \\
\hline Keywords: & $\begin{array}{l}\text { Corporate Social Responsibility, income taxes, public policy, listed } \\
\text { companies }\end{array}$ \\
\hline
\end{tabular}

\section{SCHOLARONE \\ Manuscripts}




\title{
Do income taxes affect corporate social responsibility? Evidence from European listed companies
}

\author{
Luca Gandullia* and Stefano Piserà** \\ *Department of Political Science, University of Genova \\ **Department of Economics and Statistics, University of Udine
}

\begin{abstract}
This study explores empirically the effects of corporate income taxes on the incentive to invest in Corporate Social Responsibility (CSR) activities. We estimate the relation between CSR ratings and firm-specific corporate effective tax rates for a large sample of non-financial listed companies from 15 European countries during 2006-2016. By employing an instrumental variable approach, we find that average effective tax rates (EATR) are negatively correlated with CSR ratings. Our findings are also consistent under additional tests and robustness checks. We, therefore, can provide suggestive evidence that corporate taxation discourages corporate socially responsible behaviour. At the same time, in a tax policy perspective, our analysis suggests how countries could encourage through the tax system the corporate provision of sustainable investments.
\end{abstract}

Keywords: corporate social responsibility; income taxes; tax policy; listed companies

JEL Classification Codes: H25; M14

*Corresponding author: luca.gandullia@unige.it, Phone: +39 010209 51167, via Balbi 5, 16126 Genoa, Italy. This research did not receive any specific grant from funding agencies in the public, commercial, or not-for-profit sectors. 


\title{
Do income taxes affect corporate social responsibility? Evidence from European listed companies
}

\begin{abstract}
This study explores empirically the effects of corporate income taxes on the incentive to invest in Corporate Social Responsibility (CSR) activities. We estimate the relation between CSR ratings and firm-specific corporate effective tax rates for a large sample of non-financial listed companies from 15 European countries during 2006-2016. By employing an instrumental variable approach, we find that average effective tax rates (EATR) are negatively correlated with CSR ratings. Our findings are also consistent under additional tests and robustness checks. We, therefore, can provide suggestive evidence that corporate taxation discourages corporate socially responsible behaviour. At the same time, in a tax policy perspective, our analysis suggests how countries could encourage through the tax system the corporate provision of sustainable investments.
\end{abstract}

Keywords: corporate social responsibility; income taxes; tax policy; listed companies JEL Classification Codes: H25; M14 


\section{Introduction}

Do income taxes affect corporate social responsibility (CSR)? This is the research question examined in this study with the aim to shed light on the role played by public policy and in particular tax policy in promoting corporate socially responsible behaviours.

A large literature emphasizes the importance of public policies on socially responsible value creation and CSR activities in order to improve social welfare (Albareda et al., 2007, 2008; Sarkar, 2008; Steuerer et al., 2012; Midttun et al., 2015). Over the last decade, governments have joined other stakeholders in assuming a relevant role as drivers of corporate social responsibility and adopting public sector roles in strengthening CSR (Fox et al. 2002). At the start of the century, these governmental initiatives converged with the actions of different international organizations such as the UN Global Compact and the European Commission, both of which began to promote and endorse CSR, recognizing that the role of public policy initiatives was key in encouraging corporate socially responsible behaviours. The connection between the firm's CSR activities and the public sector was recognized as a special channel to achieve sustainable and long-term development during the World Bank conference on "Public Policy and Corporate Social Responsibility" (Petkoski and Twose, 2003). One of the more concrete recommendations concerned the provision of tax-incentives to facilitate the corporate to social welfare spillovers. On the same line, a survey on recommended public policies to achieve sustainable practices suggested a "tax break" for CSR firms (Steuerer, 2010).

In the CSR economic literature, different factors are found to explain the socially responsible behaviour of companies (Liang and Renneboog 2018). However, little is known about the effects of corporate tax policy on CSR activities. Theoretical and empirical literature mainly investigated the relationship between CSR and tax avoidance, finding interesting but ambiguous results (Goerke, 2018; Huseynov and Klamm 2012; Davis et al., 2016). Recently, Lòpez-Gonzàlez et al. (2019) find that social and environmental performance is negatively related with tax avoidance so that firms with a greater socially responsible performance show a lower tax saving practices.

Trying to fill this gap our study aims at investigating the effects of corporate income taxes on the incentive to invest in CSR activities. Compared to previous tax literature, we develop a different perspective of analysis. We focus on the role played by corporate income taxes in promoting or discouraging CSR investments. To this aim, following the literature on the effects of corporate taxes on investment (e.g. Auerbach and Hassett, 1992, 2002; Djankov et al., 2010; Hassett and Hubbard, 2002), we adopt the microeconomic framework of Devereux and Griffith (2003) to calculate forward-looking effective tax rates on investment. Following the triple bottom line (TBL) approach (Elkington 1994) we consider the CSR as all corporate practices affecting the environmental, social and governance sphere. The higher (lower) the environmental, social and governance corporate commitment, the higher (lower) the corporate social responsibility activities. For our purpose, the TBL approach to CSR is the most appropriate framework to take into account not only the total corporate sustainability commitment, but also both environmental and social production externalities. 
In this context, we estimate the relation between CSR ratings and firm-specific corporate effective average tax rates (EATRs) for a large sample of non-financial listed companies from 15 European countries during 2006-2016. We find that EATRs are negatively correlated in a statistically significant way with CSR ratings. We, therefore, can provide suggestive evidence that corporate taxation discourages CSR activities and that conversely it can be used as an instrument to boost CSR investment.

The paper contributes to the literature in several ways. First, it speaks to the general literature on the determinants of CSR and adds to the understanding of the role played by corporate taxes in promoting socially responsible behaviour. Our research speaks directly to the nature of the causal path from corporate income taxes to CSR, which is unique in the CSR literature. Second, in a tax policy perspective, it suggests how countries could incentivize through the tax system the corporate provision of public goods. To our knowledge, ours is the first attempt to provide genuine causal and empirical evidence about the influence of tax policy on CSR and our data clearly document such a relationship. Our findings contribute to the CSR literature by documenting an important and previously unexamined driver of CSR.

The remainder of the paper is organized as follows. In Section 2, we present the theoretical framework and our research hypothesis; in Section 3 we illustrate the methodology and the empirical strategy. Section 4 presents the results. Section 5 discusses the results and concludes the paper.

\section{Theoretical framework and research hypothesis}

As is well known, CSR spans multiple dimensions of firm behaviour. It captures a firm's effort to address various externalities that it generates in the process of pursuing profit maximization (Tirole 2001). These externalities are not entirely internalized by shareholders (Magill, Quinzii, and Rochet, 2015). Theoretical and empirical literature shows that firms voluntary produce (impure) public goods or correct negative externalities jointly with their main task to provide private goods, independent of legal benchmarks (Kitzmueller and Shimshack, 2012; Besley and Ghatak, 2007; Benabou and Tirole, 2009). In the literature, the view of CSR activities as a firm's investment has been discussed since its foundation. Specifically, it has been argued (Kitzmueller and Shimshack, 2012) that CSR may constitute, rather than a pure form of corporate expenditure (i.e. it simply is a static cost parameter), a special form of investment into innovation. As such CSR investments are actions that address environmental or social impact, while at the same time improving a firm's competitiveness (Porter, 1991; Porter and van der Linde, 1995) in a long-term perspective (Bénabou and Tirole, 2010; Baron 2001).

The common explanation for why companies invest in CSR is that doing so enhances profitability and firm value, a relationship often referred to as "doing well by doing good" (Renneboog et. al., 2008, 2011; Guenster et al., 2011; Deng et al., 2013; Flammer, 2015; Krueger, 2015). Jiao (2010) argues that a positive effect of CSR on corporate performance is consistent with the view that CSR represents an investment in intangible assets (such as reputation 
and human capital), which contribute to enhancing firms' competitiveness ${ }^{1}$. In a more recent contribute Sun and Gunia (2018) explore the link between economic resources and CSR. They stress the importance of the firm's condition on CSR activities and the positive relationship between the increasing of economic resources and CSR investments.

In the CSR literature little is known about the effects of tax policy on corporate socially responsible behaviours. Theoretical and empirical literature mainly questioned whether corporate tax payments and CSR act as complements or substitutes (Goerke, 2018). Empirical research suggests competing predictions about the relationship between tax payments and CSR (Laguir et al., 2015; Landry et al., 2013; Lin et al., 2017). Some studies find a positive relationship (Huseynov and Klamm 2012), while others (Davis et al., 2016; Lòpez-Gonzàlez et al., 2019) find results of opposite sign.

Following the view that CSR represents an investment in intangible assets, the most appropriate framework to analyse the effects of taxes on CSR investments is offered by the theoretical and empirical literature on corporate taxation. If firms regard CSR as one of several investment options, then changes in taxes and then in profitability could influence CSR investments much as these changes influence other investment decisions. The linkage between corporate taxation and firm economic performance has received persistent attention in both the academic literature and policy debates. It is well understood that corporate taxation can have large effects on firms' investment decisions. Corporate taxes impinge directly on the incentive to accumulate capital and to invest in innovation (Feldstein et al., 1983; Auerbach, 1983, 2002; King and Fullerton, 1984; Auerbach and Hassett, 1992, 2002; Cummins, Hassett, and Hubbard, 1996; Djankov, Ganser, McLiesh, Ramalho and Shleifer, 2010; Hassett and Hubbard, 2002; Hines, 2001, 2007). Fazzari, Hubbard, and Petersen (1988) and Devereux and Griffith (2003) point out that corporate taxes affect investment by reducing current period cash flow available to fund it.

In the empirical literature, most studies employ the cost of capital approach dating back to Jorgenson (1963), Hall and Jorgenson (1967), and King (1974), and further developed by Devereux and Griffith (1998, 2003). This method exploits variation of the tax-adjusted user cost over time or across sectors to detect the impact on investment choices. In the Devereux and Griffith's framework (2003) a well-established methodology has been developed to calculate forward-looking effective tax rates on the basis of prospective, or hypothetical, investment projects. The advantage of this approach is that it allows for cross-country comparisons of the effect of taxes on the incentive to invest (Spengel et al. 2018).

Following the view that CSR represents an investment and according to the corporate tax literature, we formulate the following research hypotheses:

H1: The relation between corporate effective tax rates and CSR, Environmental and Social ratings is negative

\footnotetext{
${ }^{1}$ A negative effect of CSR on performance is consistent with the view that CSR represents private benefits (e.g., respect, job security, public image) that managers extract at the expense of shareholders.
} 


\section{Methodology}

We randomly selected a sample of 236 European listed non-financial companies, according to the Thomson Reuters Business Classification (TRBC), from 2006 to 2016 and the environmental (E), social (S) and ESG score components from Thomson Reuters's ASSET4, as a proxy of the level of CSR (see e.g Liang and Renneboog 2017, Arouri et al 2019). The CSR score used in our sample is a weighted average of ESG scores ranged from 0 to 100 (highest CSR level). Our dataset covers non-financial companies, from 15 countries (Great Britain, Ireland, Denmark, Sweden, Portugal, Norway, Netherlands, Luxemburg, Italy, France, Finland, Spain, Denmark, Germany, Belgium). ASSET 4 provides data about ESG aggregated score and single Environmental (ENV), Social (SOC) and Governance (GOV) factors. However, in order to test our hypothesis, we focused only on ESG aggregated score (as a proxy of firm CSR level), E and S pillars. Following Thomson Reuters, the ESG score measure is a combination of 10 categories composing the three single pillars which reflects the company's CSR performance and commitment. All single score can take a value from 0 (worst corporate performance) to 100 (best corporate performance) and, according to Thomson Reuters database, is composed on three sub-categories, which, aggregated, form the single pillar. In order to test our hypothesis, we calculated the CSR, ENV and SOC pillars as suggested by the last available methodology by Thomson Reuters (Thomson Reuters ESG scores, February 2019). More precisely, the calculation of ESG is composed by the following weights and components: the 34\% of ENV score, the $35.5 \%$ of SOC score and the $30.5 \%$ of GOV score. The ENV score is composed of "Resource use" (11 \%) score, the "Emission" score (12\%) and the "Innovation" score (11\%). The SOC score is based on the "Workforce" score (16 \%), the "Human Rights" score (4.5\%), the "Community" score (8\%) and the "Product Responsibility" score (7\%).

\subsection{Taxation measures}

We follow the Devereux and Griffith's framework (2003), which allows computing firm-specific effective tax rates. In this context, a firm at time $t$ increases its capital stock by one unit; at time $t+1$, this investment is worth (1 $-\delta)(1+\pi)$ where $\delta$ is the depreciation rate and $\pi$ the inflation rate. The investment return at time $t+1$ can be expressed as $(p+\delta)(1+\pi)$, where $p$ is the real financial rate of return of the investment. In the absence of taxation the net present value of the economic rent produced by the investment $\left(R^{*}\right)$ will be independent from the source of finance (equity, debt) and can be expressed as follows:

$$
\mathrm{R}^{*}=(\mathrm{p}-\mathrm{r}) /(1+\mathrm{r})
$$

where $r$ measures the real interest market rate.

The introduction of the tax system changes this result and the post-tax net present value will depend on how the investment is financed (retained earnings, issues of new shares, debt financing). The empirical analysis of this 
paper uses the average effective tax rates (EATRs). EATRs analyse how the tax system influences binary choices decisions of the company, for instance, the choice a firm faces when deciding whether or not to undertake a specific type of investment. Specifically, EATRs measure the average tax burden on an investment giving a predetermined rate of profitability. EATRs are calculated as the difference between the pre-tax net present value of investment $R^{*}$ (Equation 1) and its after-tax net present value $(R)$ over the pre-tax rate of return on capital, defined by the ratio between the rate of profitability $p$ and $(1+r)$, where $r$ is the market interest rate:

$$
\mathrm{EATR}=\left(\mathrm{R}^{*}-\mathrm{R}\right) / \mathrm{p} /(1+\mathrm{r})
$$

In our analysis, we estimated effective average corporate tax rates (ETRs) based on Spengel et al. (2018). We calculated the firm-specific effective tax rate, weighting the tax rate on the firm's specific debt to equity ratio and industry (based on information available in our companies data-set).

\subsection{Control Variables}

We include a set of control variables to account for the relationship between EATR and CSR (Liang and Renneboog 2018; Ferrel et al., 2016). We include two different sets of control variables: at corporate and macro levels. The set of corporate controls include: the liquidity ratio (LIQ) calculated as the ratio between total cash on total asset, the return on asset (ROA) calculated as the earnings before interest, tax and depreciation on the total asset ratio, the size (SIZE) calculated as the natural logarithm of total asset, the leverage (LEV) computed as the total debt to total asset ratio, and the capital expenditure scaled on total asset (CAPEX). All corporate control variables come from the Thomson Reuters ASSET4 database and are based on our calculation as explained before. According to the literature, the CSR investing could be influenced by other sovereign and macro-economic conditions. To this aim we include also the following sovereign variables: the KOF index of globalization, the GDP pro capita (GDP PC) provided by the IMF database, the government effectiveness index (GOV EFF) to control for the perceptions of the quality of public services (World Bank database), the index of the political constraints (POLCON), that take into account the strength of political limits (provided by the Wharton University of Pennsylvania), the index of investor protection (INVEST PROT) (World Bank database), the economic freedom index (ECO FREE) (World Bank database) and the control corruption index (CONTR CORR) (World Bank database). Finally, we control also for year and industry and firm fixed effect, clustering the standard error at the firm level (Ferrell et al 2016) by performing different econometric models. Following Iacobucci et al (2015), we yearly and country (year country) centered the GOV EFF and ECO FREE index, in order to reduce the correlation problems among regressors (corr $>0.46$ ). 


\subsection{Empirical strategy}

According to the literature that finds adverse effects of corporate income taxes on investment (Hassett and Hubbard, 2002; Hassett and Glenn, 2002; Djankov et al., 2010; Ohrn, 2018), our prediction is that corporate taxes can discourage socially responsible activities, reflected by CSR ratings. The recent literature on CSR investments (Soytas et al 2019) casts doubt on the possibility of endogeneity problems between CSR and firm's financial performance. Lee et al. (2015) find a statistically positive relationship between corporate sustainability and financial performance, while Lourenco et al. (2012) stress the reverse causal link. Endogeneity concerns are raised also in the literature on CSR and tax avoidance (Lopez-Gonzalez et al., 2018, Huseynov and Klamm 2012). For our purpose, endogeneity could rise by both reverse causalities (EATR - CSR) and by the correlation between the independent variables and error term. In order to avoid endogeneity problems, we employ the Instrumental Variables (IV) (Ferrell et al 2016) Generalized Method of Moments (GMM) (Sheikh, 2018; Sheikh 2019; Zolotoy et al 2019) technique with year, industry fixed effect and cluster at the firm level (Ferrel et al 2016; Zolotoy et al 2019). One of the reasons we adopt the IV-GMM is that by run the IV-GMM the model parameters are estimated in a single step, improving the estimation efficiency (e.g., Cameron and Trivedi, 2005) while in the classic IV 2sls this does not happen. In line with the literature (see e.g Woolridge 2015; Minnick et al 2017; Lin et al., 2011; Laeven and Levine, 2009) we instrument the potentially endogenous variable (the EATRs) on its own lagged values in our baseline model (table 3). Table 3 shows the second stage of the IV GMM by controlling for the possible endogeneity of our target variable (EATRs). According to the previous studies (Minnick et al 2017, Coglianese et al 2017, Woolridge 2015, Keen and Syed 2006), the lagged values of tax rates could be considered as valid instruments of current tax rates, especially due to its high correlation with the current tax rates. However, the IV GMM method needs further econometric tests, such as the Cragg-Donald first stage f-statistic, the Sargan's p and Hansen's J values, to correctly stress the use of good and unbiased instruments (Durbin, 1954; Hausman, 1978; $\mathrm{Wu}, 1973)$. As shown in Table 3, all these three tests confirm the adequate choice of instrumental variable involved.

However, following the literature (Ferrel et al 2016), endogeneity bias could also arise from other regressors, such as the SIZE, LIQ, ROA, LEV, CAPEX (Table 4). To test the robustness of our results, in Table 4 we show the second stage of IV GMM by instrumenting not only our target variable (EATRs) but also the SIZE, LIQ, ROA, LEV, CAPEX with the within-sample arithmetic means of each our five corporate independent variables by country, industry and year (country-industry-year average) (Table 4). The use of industry peers' average financial policies (SIZE, LIQ, LEV, CAPEX) and performances (ROA) as IVs is in line with the literature showing that a firm's financial strategy is influenced by the performance and policies of its peer firms (Leary and Roberts, 2014) and that a firm's CSR practice is affected by its peer firms' financial policies through channels other than influencing its financial policies. Following the literature, the peer effects are the leading determinants of capital structure determination (e.g., Hoberg, Phillips, and Prabhala 2014), and corporate investment decisions (Foucalt and Fresard, 2014 ). In line with studies mentioned before, and as shown in table A2, our instruments satisfy the 
rule of thumb assessing the quality of instrumental variables: the high correlation with the instrumented variables (robust instruments), shown by high values (>16.38) of the Cragg-Donald first stage f-statistic (Table A2). Table A2 shows the first-stage of IV-GMM methods, to stress the individual validity of IVs employed in second- stage of IV-GMM (Table 3 and Table 4). The benefit of running an IV GMM comes from the capacity to control for endogeneity, providing greater consistency, explanatory power and general efficiency. Moreover, we control for industry and time fixed effects, which mitigate concerns that unobservable firm characteristics or time trends could drive our results. As of last robustness checks, we employ a panel fixed effect regression model with the same corporate effective tax rates (EATRs), showing that our results hold also without the use of IVs (Table 5)

\section{Results}

\subsection{Descriptive results}

Table 1 reports the mean and standard deviation of the variables. SOC, ENV and CSR scores are our dependent variables with average values (82, 79 and 76 per cent respectively). These results show a first picture of the way the social dimension is developed among European firms.

The correlation matrix (Table 2) shows a low correlation among variables.

Table 1: Descriptive statistics

Table 2: Correlation Matrix

\subsection{Corporate effective taxation and CSR}

Table 3, 4 and 5 report the results of the second sage of the IV GMM regression. The EATR is strongly negatively correlated with CSR $(-0.716 \mathrm{p}<0.01)$, ENV $(-0.354 \mathrm{p}<0.01)$ and SOC $(-0.380 \mathrm{p}<0.01)$ score. Our results support $\mathrm{H} 1$, letting us stress a negative relationship between corporate income taxes and corporate sustainable performances. More precisely, a one standard deviation increase of EATRs reduce by $1.52 \%(-0.380 * 4)$ (table 3 ) the ability of firms to develop "sustainable products", respect "human rights", the "local community" and the "workforce" involved in the value creation processes. An increase of one standard deviation of EATRs discourages the "emission" reduction, the "resource use" valorisation, and "environmental innovation" by $1.41 \%$ and $2.9 \%$ (table 3) of the total ability of firms of being socially responsible and play an active role on the Socially development goals (SDG) achievement. Looking at the controls, firms with higher CSR ratings are larger firms with a higher return on asset, located in countries that are more globalized (as captured by the KOF globalization index, ECO FREE and INVEST PROT) and better governed (as showed by GOV EFF, CONTR CORR). All these 
corporate controls variables are in line with the literature on CSR determinants (Liang and Renneboog 2018; Boubakri et al., 2019; Sun and Gunia 2018).

Nevertheless, the IV approach requires several post-estimations tests, such as the Sargan test, the Hansen test and the Cragg-Donald f-test statistics to be considered as a valid method (Woolridge, 2015, Durbin, 1954; Hausman, 1978; Wu, 1973). As shown in table 3 and 4, the Sargan's p-value is $>0.1$ for all CSR, ENV and SOC score, allowing us to do not reject the Sargan's null hypothesis and to successfully consider all variables as exogenous. The second post-estimation step is the overidentification test (Hansen's $\mathrm{j}$ ), which for values greater than 0.1 stress the correct specification of the model, the validity of instrument adopted and the goodness of specified structural equation. The third check regards the validity of the instruments used. As shown in Table A2, the Cragg-Donald ftest statistics is always higher than the critical value of 16.38 , with P-values smaller than 0.01 in all specifications.

Table 3: Main results of second-stage IV-GMM of ETRs and CSR, ENV and SOC

As additional robustness check (Table 5) we run a panel fixed effect regression; the negative relationship between EATRs and all three dependent variables is confirmed.

As shown in Table 3, 4 and 5, the EATRs are always in a statistically significant way negatively correlated with CSR, ENV and SOC scores. More precisely, the stronger negative impact of tax rates is that related to the ability of firms to pursue sustainable practices (CSR) maximizing shareholder wealth as well as achieving broader societal goals. Moreover, our baseline analysis (Table 3 and Table 4) by disentangling the CSR score into two of its three components (E, S and G), allows us to stress that the SOC pillar is the component which is most discouraged by higher EATRs.

Table 4: Alternative second-stage IV GMM of ETRs and CSR, ENV and SOC

Table 5: Fixed effect regression results of EATRs, CSR, ENV and SOC score

\section{Conclusions}

We explored the impact of corporate taxes in Europe during the period 2006-2016 on the level of corporate social responsibility for non-financial listed companies, by regressing the firm-specific effective tax rates on the CSR score. We run different econometrics tests showing that the effective average corporate taxes strongly reduce the CSR level of European companies. To assess the impact of EATR on corporate sustainable practices, our study focuses also on the firm's environmental and social performances, because they provide a standard example of 
economic externalities (Chen et al 2018). We, therefore, can provide suggestive evidence that corporate taxation discourages CSR activities. At the same time, we also stress the connection between CSR disclosure and institutional framework (Chen et al. 2018; Ferrel et al 2016).

The economic literature (Kitzmueller and Shimshack, 2012) argues that only if governments fail to deliver optimal levels of public good, will CSR be potentially efficient; however, it outlines conditions under which CSR may produce higher social welfare gains than public or other private provision channels. In a tax policy perspective, our analysis also suggests how countries could incentivize through the tax system the corporate provision of public goods. The above results support that government highly focused on promoting sustainable development and corporate to social welfare spillover effects (Albareda et al., 2007, 2008; Midttun et al., 2015) should reduce the effective corporate taxation (Steuerer 2010), also through tax incentives along the well-known model of tax credit on R\&D investment.

Our paper contributes to the debate on CSR and sustainable development in three ways. Firstly, it empirically shows the negative impact of corporate taxes on CSR engagement, suggesting how to improve social welfare by encouraging corporate welfare. Secondly, it shows how corporate taxes differently affect the social (SOC) and environmental (ENV) dimension of a firm's sustainable investing. Thirdly, we stress a public policy strategy through which European countries, by reducing corporate effective taxation, could encourage corporate disclosure and social responsibility of both large and small and medium companies.

Nonetheless, our results are subject to certain limitations. First, the main limitation corresponds to the CSR measure, which is provided by only one provider (Thomson Reuters). Although this measure has been used in several previous studies (e.g., Ferrel et al 2016; Liang and Renneboog 2017), future research could try to examine our research questions by using alternative environmental and social measures. Second, our sample of analysis is restricted to specific countries and for the period 2006-2016. Future studies could reinforce the results by enlarging the period and the sample of analysis to additional countries.

\section{References}

Albareda, L., Lozano, J.M., Tencati, A., Midttun, A., Perrini, F. (2008). The changing role of governments in corporate social responsibility: drivers and responses. Business Ethics: A European Review, Vol. 17, N. 4, October

Albareda, L., Lozano, J.M., Ysa, T. (2007). Public Policies on Corporate Social Responsibility: The Role of Governments in Europe, Journal of Business Ethics, September, Vol. 74, Issue 4, pp 391-407 
Arouri,M., Gomes,M., K., Pukthuanthong (2019). Corporate social responsibility and M\&A uncertainty. Journal of Corporate finance. Vol.56, 176-198

Auerbach, A. J. (1983). Taxation, corporate financial policy and the cost of capital. Journal of Economic Literature, 21, 905940

Auerbach, A. J. (2002). Taxation and corporate financial policy. In A. Auerbach \& M. Feldstein (Eds.), Handbook of public economics (Vol. 3, pp. 1251-1292). Amsterdam: North-Holland.

Auerbach, A. J., \& Hassett, K. (1992). Tax policy and business fixed investment in the United States. Journal of Public Economics, 47, 141-170

Auerbach, A. J., Hassett, K. (2002). Taxation and economic efficiency. In A. Auerbach \& M. Feldstein (Eds.), Handbook of Public Economics (Vol. 3, pp. 1347-1421). Amsterdam: Elsevier.

Baron, D. (2001). Private politics, corporate social responsibility and integrated strategy. Journal of Economics and Management Strategy, 10, 7-45.

Bénabou, R., Tirole, J. (2010). Individual and Corporate Social Responsibility. Economica, Volume77, Issue305 January, 1-19

Besley, Timothy and Ghatak, Maitreesh, (2007). "Retailing public goods: The economics of corporate social responsibility," Journal of Public Economics, Elsevier, vol. 91(9), pages 1645-1663, September.

Boubakri, N., Guedhami, O., Kwok, C. C. Y., Wang, H. (2019). Is privatization a socially responsible reform?. Journal of corporate finance, $\mathrm{Vol} 56,129-151$

Cameron, A.C., Trivedi, P.K. (2005). Microeconometrics: Methods and Applications. Cambridge University Press .

Coglianese, J., Davis, L.W., Kilian, L., Stock, J. H. (2017). Anticipation, Tax avoidance and the price elasticity of gasoline demand. Journal of applied econometrics. Vol.32,1-15

Chen, Y. C., Hung, M., Wang, Y. (2018). The effect of mandatory CSR disclosure on firm profitability and social externalities: Evidence from China, Journal of Accounting and Economics, Vol.65, 169-190

Cummins, J. G., Hassett, K. A., \& Hubbard, R. G. (1996). Tax reforms and investment: A cross-country comparison. Journal of Public Economics, 62, 237-273

Davis, A. K., Guenther, D.A., Krull, L. K., and Williams, B. M. (2016). Do Socially Responsible Firms Pay More Taxes?, The Accounting Review: January 2016, Vol. 91, No. 1, pp. 47-68.

Deng, Xin, Jun-koo Kang, and Buen Sin Low (2013). Corporate social responsibility and stakeholder value maximization: evidence from mergers, Journal of Financial Economics 110, 87-109

Devereux, M., \& Griffith, R. (1998). The taxation of discrete investment choices (IFS Working Paper 98/16). London: IFS Devereux, M.P. and R. Griffith (2003). Evaluating Tax Policy for Location Decisions, International Tax and Public Finance, $10(2), 107-126$ 
Djankov, S., Ganser, T., McLiesh, C., Ramalho, R., \& Shleifer, A. (2010). The effect of corporate taxes on investment and entrepreneurship. American Economic Journal Macroeconomics, 2, 31-64

Durbin, J. (1954). Errors in variables. Review of International Statistical Institute. 22, 23-32.

Elkington, J. (1997). Cannibals with Forks. The Triple Bottom Line of 21st Century. New Society Publisher

Fazzari, S., Hubbard, R. G., Petersen, B. (1988). Investment, financing decisions, and tax policy. American Economic Review, 78, 200-205

Feldstein, M., Dicks-Mireaux, L., Poterba, J. (1983). The effective tax rate and the pretax rate of return. Journal of Public Economics, 21, 129-158

Ferrel, A., Liang, H., Renneboog, L. (2016). Socially responsible firms. Journal of financial economics, Vol. 122,585-606

Flammer, C. (2015). Does corporate social responsibility lead to superior financial performance? A regression discontinuity approach, Management Science 61, 2549-2568.

Foucalt, T. , Fresard, L. (2014). Learning from peers' stock prices and corpo- rate investment. Journal of Financial Economics $111,554-577$

Fox, T., Ward, H. and Howard, B. (2002). Public Sector Roles in Strengthening Corporate Social Responsibility: A Baseline Study. Washington, DC: World Bank.

Goerke, L. (2018). Corporate social responsibility and tax avoidance, Journal of Public Economic Theory. 2018 ; 1-22.

Guenster, Nadja, Rob Bauer, Jeroen Derwall, and Kees Koedijk (2011). The economic value of corporate eco-efficiency, European Financial Management 17, 679-704.

Hall, R. E., \& Jorgenson, D. (1967). Tax policy and investment behavior. American Economic Review, 57, 391-414

Hassett, K., \& Hubbard, R. G. (2002). Tax policy and business investment. In M. Feldstein \& A. Auerbach (Eds.), Handbook of public economics (Vol. 3, pp. 1293-1343). Amsterdam: North-Holland

Hassett, K., and Glenn, H. (2002). Tax Policy and Business Investment, in Alan Auerbach and Martin Feldstein (eds.), Handbook of Public Economics, Vol. 3, 1293-1343. Amsterdam: North-Holland

Hausman, J. A. (1978). Specification tests in econometrics. Econometrica, 46(6), 1251-1271.

Hines, J. R. (2001). Corporate taxation. In N. J. Smelser \& P. B. Baltes (Eds.), International encyclopedia of the social \& behavioral sciences (pp. 2810-2812). Kidlington: Elsevier Science

Hines, J. R. (2007). Corporate taxation and international competition. In A. J. Auerbach, J. R. Hines, \& J. Slemrod (Eds.), Taxing corporate income in the 21st century (pp. 268-295). New York, NY: Cambridge University Press

Hoberg, G., Phillips, G., Prabhala, N. (2014). Product market threats, pay- outs, and financial flexibility. Journal of Finance. 69 (1), 293-324 
Huseynov, F., \& Klamm, B. K. (2012). Tax Avoidance, Tax Management and Corporate Social Responsibility. Journal of Corporate Finance, 18(4), 804-827

Iacobucci, D., Schneider, J.M., Popovic, L. D., Bakamitsos, A.G. (2016). Mean centering helps alleviate "micro" but not "macro" multicollinearity. Behaviour Research methods, Vol.48,1308-1317

Jiao Y. (2010). Stakeholder welfare and firm value, Journal of Banking and Finance, 34, 2549-2561

Jorgenson, D. (1963). Capital theory and investment behavior. American Economic Review, 52, 305-360

Keen, M., Syed, M. (2006). Domestic Taxes and International Trade: Some Evidence. USA: International Monetary Fund.

King, M. (1974). Taxation and the cost of capital. The Review of Economic Studies, 41, 21-35

King, M., \& Fullerton, D. (1984). The taxation of income from capital. Chicago, IL: Chicago University Press

Krueger, P. (2015). Corporate goodness and shareholder wealth, Journal of Financial Economics 115, 304-329

La rosa, F., Liberatore, G., Mazzi, F., Terzani, S. (2018). The impact of corporate social performance on the cost of debt and access to debt financing for listed European non-financial firms. European Management Journal, Vol.36, (4), 519-529

Laguir, I., Staglianò, R., \& Elbaz, J. ( 2015). Does corporate social responsibility affect corporate tax aggressiveness? Journal of Cleaner Production, 107, 662 - 675.

Landry, S., Deslandes, M., \& Fortin, A. (2013). Tax aggressiveness, corporate social responsibility and ownership structure. Journal of Accounting, Ethics \& Public Policy, 14( 3).

Lin, K. Z., Cheng, S., \& Zhang, F. ( 2017). Corporate social responsibility, institutional environments, and tax avoidance: Evidence from a subnational comparison in China. The International Journal of Accounting, 52( 4), 303-318

Lòpez-Gonzàlez, E., Martìnez-Ferrero, J., Garcìa-Meca, E. (2019). Does corporate social responsibility affect tax avoidance: Evidence from family firms, Corporate Social Responsibility and Environmental Management, 1-13.

Laeven, L., Levine, R. (2009). Bank governance, regulation, and risk taking. Journal of Financial Economics 93, 259-275

Leary, M., Roberts, M. (2014). Do peer firms affect corporate financial policy? .Journal of Finance 69 (1), 139-178

Lee, K.H., Min, B., Yook, K.H. (2015). The impacts of carbon (CO2) emissions and environmental research and development(R\&D) investment on firm performance. Int. J. Prod. Econ. 167, 1-11.

Liang, H., Renneboog, L. (2017). On the Foundation of Corporate Social Responsibility. Journal of Finance, Vol LXXI (2), 853-909

Lin, C. , Malatesta, P. , Xuan, Y. (2011). Ownership structure and the cost of corporate borrowing. Journal of Financial Economics 100, 1-23. 
Lirio, J.R.M., Torres, M.J. (2010). The effectiveness of the Public support Policies for the European Industry Financing as a contribution to Sustainable Development. Journal of Business Ethics.Vol.94,489-515

Liu, Q., Wang, F.S.L., Chen, L.C. (2018). CSR in Oligopoly with foreign competition: Policy and Welfare implication. Economic Modelling, Vol.72,1-7

Lourenco, I.C., Branco, M.C., Curto, J.D., Eugenio, T. (2012). How does the market value corporate sustainability performance? J. Bus. Ethics 108, 417-428.

Magill, M., Quinzii, M. Rochet, J. C. (2015). A theory of the stakeholder corporation, Econometrica 83 (5), $1685-1725$.

Midttun, A., Gjølberg, M., Kourula, A., Sweet, S., Vallentin, S. (2015). Public Policies for Corporate Social Responsibility in Four Nordic Countries: Harmony of Goals and Conflict of Means, Business \& Society 2015, Vol. 54(4) 464-500

Minnick,K., Noga,T.(2017). The influence of firm and industry political spending on tax management among S\&P 500 firms. Journal of Corporate Finance.Vol.44,233-254

Kitzmueller, M., Shimshack, J. (2012). Economic Perspectives on Corporate Social Responsibility. Journal of Economic literature, Vol. 50, n. 1, 51-84

Ohrn, E. (2018). The Effect of Corporate Taxation on Investment and Financial Policy: Evidence from the DPAD. American Economic Journal: Economic Policy. 272-301

Petkoski, D., Twose, N. (Eds) (2003). Public Policy and Corporate Social Responsibility, World Bank Institute

Porter, Michael E. (1991). America’s Green Strategy. Scientific American 264 (4): 168.

Porter, Michael E., and Claas van der Linde (1995). "Toward a New Conception of the Environment-Competitiveness Relationship, Journal of Economic Perspectives 9 (4): 97-118.

Renneboog, Luc, Jenke TerHorst, and Chendi Zhang (2008). The price of ethics and stakeholder governance: The performance of socially responsible mutual funds. Journal of Corporate Finance. Vol. 14, 302-322.

Renneboog, Luc, Jenke Ter Horst, and Chendi Zhang (2011). Is ethical money financially smart? Nonfinancial attributes and money flows of socially responsible investment funds. Journal of Financial Intermediation. Vol. 20, 562-588.

Sarkar, R. (2008). Public Policy and Corporate Environmental Behaviour: a Broader View. Corporate Social Responsibility and Environmental Management, Vol. 15, 281-297

Sheikh, S. (2018). Corporate social responsibility, product market competition, and firm value. Journal of Economics and Business. Vol.98, 40-55

Sheikh, S. (2019). Corporate social responsibility and firm leverage: The impact of market competition. Research in International Business and Finance. Vol. 48, 496-510 
Soytas, M.A., Denizel, M., Usar, D.,D. (2019). Addressing endogeneity in the causal relationship between sustainability and financial performance. International Journal of Production Economics, Vol. 210, 56-71

Spengel, C., Dieter, E., Finke, K., Heckemeyer, J. (2018). Effective tax levels using the Devereux/ Griffith methodology, Final Report 2017, ZEW, Mannheim

Steurer, R. (2010). The Role of Governments in Corporate Social Responsibility: Characterising Public Policies on CSR in Europe. Policy Sciences, 43/1, 49-72

Steurer, R., Martinuzzi, A., Margula, S. (2012). Public Policies on CSR in Europe: Themes, Instruments, and Regional Differences, Corporate Social Responsibility and Environmental Management, Volume 19, Issue 4

Sun, X., Gunia, B., C. (2018). Economic resources and Corporate Social Responsibility. Journal of corporate finance, Vol 51, $332-351$

Tirole, J. (2001). Corporate governance, Econometrica 69, 1-35.

Toder-Alon, A., Rosenstreich, E., Te'eni Harari, T. (2019). Give or take? Consumers' ambivalent perspectives on the relationship between a firm's corporate social responsibility engagement and its responsible tax payments. Corporate Social Responsibility and Environmental Management, Volume 26, Issue 4

Wagner et al. 2002. The relationship between the environmental and economic performance of firms: an empirical analysis of the European paper industry. Corporate Social Responsibility and Environmental Management, 9(3): 133-146

Woolridge, J.M. (2015). Introductory econometrics: A modern Approach. South-Western College Pub; 6 edition

Wu, D. M. (1973). Alternative tests of independence between stochastic regressors and disturbances. Econometrica, 41(4), 733-750.

Zolotoy, L., O’Sullivan, D., Chen, Y. (2019). Local religious norms, corporate social responsibility, and firm value. Journal of Banking and Finance. Vol.100, 218-233 


\begin{tabular}{cccc}
\hline Variable & Nuber of Observations & Mean & Std.Dev. \\
CSR & & & 76 \\
ENV & 2101 & 79 & 21 \\
SOC & 2101 & 82 & 18 \\
EATR & 2101 & 24 & 4 \\
LIQ & 2279 & 0.06 & 0.06 \\
ROA & 2309 & 0.13 & 0.08 \\
SIZE & 2318 & 17 & 1 \\
LEV & 2326 & 0.27 & 0.15 \\
CAPEX & 2324 & 0.04 & 0.03 \\
KOF & 2318 & 87 & 2 \\
GDP PC & 1931 & 45962 & 11394 \\
GOV EFF & 2366 & 1.55 & 0.36 \\
POLCON & 2234 & 0.48 & 0.08 \\
CONTR CORR & 2267 & 1.66 & 0.49 \\
INVEST PROT & 2264 & 6 & 1 \\
ECO FREE & 2242 & 71 & 5.64 \\
\hline
\end{tabular}

Table 2: Correlation Matrix

\begin{tabular}{|c|c|c|c|c|c|c|c|c|c|c|c|c|c|c|}
\hline & CSR & EATR & ROA & CAPEX & LEV & LIQ & SIZE & KOF & $\begin{array}{c}\text { GDP } \\
\text { PC }\end{array}$ & $\begin{array}{l}\text { GOV } \\
\text { EFF }\end{array}$ & POLCON & $\begin{array}{c}\text { ECO } \\
\text { FREE }\end{array}$ & $\begin{array}{c}\text { INVEST } \\
\text { PROT }\end{array}$ & $\begin{array}{c}\text { CONTR } \\
\text { CORR }\end{array}$ \\
\hline CSR & 1 & & & & & & & & & & & & & \\
\hline EATR & -0.013 & 1 & & & & & & & & & & & & \\
\hline ROA & -0.081 & -0.180 & 1 & & & & & & & & & & & \\
\hline CAPEX & 0.040 & 0.031 & 0.271 & 1 & & & & & & & & & & \\
\hline LEV & 0.009 & 0.242 & -0.101 & 0.051 & 1 & & & & & & & & & \\
\hline LIQ & -0.081 & -0.021 & 0.080 & -0.060 & -0.210 & 1 & & & & & & & & \\
\hline SIZE & 0.350 & 0.290 & -0.301 & 0.050 & 0.170 & -0.220 & 1 & & & & & & & \\
\hline $\mathrm{KOF}$ & -0.021 & -0.291 & 0.080 & -0.110 & -0.220 & 0.061 & -0.231 & 1 & & & & & & \\
\hline GDP PC & -0.181 & -0.360 & 0.110 & -0.040 & -0.090 & 0.002 & -0.131 & 0.340 & 1 & & & & & \\
\hline GOV & & & & & & & & & & & & & & \\
\hline EFF & 0.010 & -0.061 & -0.030 & -0.020 & 0.020 & -0.040 & -0.031 & -0.020 & 0.030 & 1 & & & & \\
\hline $\begin{array}{l}\text { POLCON } \\
\text { ECO }\end{array}$ & -0.10 & -0.220 & -0.010 & -0.070 & -0.040 & -0.030 & 0.031 & 0.201 & 0.240 & 0.050 & 1 & & & \\
\hline $\begin{array}{l}\text { FREE } \\
\text { INVEST }\end{array}$ & -0.070 & 0.141 & 0.007 & 0.070 & 0.013 & 0.061 & -0.051 & -0.051 & 0.130 & 0.030 & -0.021 & 1 & & \\
\hline $\begin{array}{l}\text { PROT } \\
\text { CONTR }\end{array}$ & 0.090 & -0.311 & 0.161 & 0.070 & 0.011 & -0.020 & -0.301 & 0.241 & -0.170 & 0.050 & -0.450 & -0.022 & 1 & \\
\hline CORR & 0.021 & 0.140 & 0.020 & 0.060 & -0.011 & -0.060 & 0.012 & -0.091 & 0.160 & 0.020 & 0.101 & 0.161 & -0.190 & 1 \\
\hline
\end{tabular}


Table 3: Main results of second-stage IV-GMM of ETRs and CSR, ENV and SOC

\begin{tabular}{|c|c|c|c|}
\hline & $\begin{array}{c}(1) \\
\text { CSR }\end{array}$ & $\begin{array}{c}(2) \\
\text { ENV }\end{array}$ & $\begin{array}{c}(3) \\
\text { SOC }\end{array}$ \\
\hline EATR & $\begin{array}{c}-0.716^{* * *} \\
(0.060)\end{array}$ & $\begin{array}{c}-0.354 * * * \\
(0.069)\end{array}$ & $\begin{array}{c}-0.380 * * * \\
(0.060)\end{array}$ \\
\hline ROA & $\begin{array}{c}1.985 \\
(6.249)\end{array}$ & $\begin{array}{l}-3.806 \\
(5.802)\end{array}$ & $\begin{array}{l}11.27 * * \\
(5.258)\end{array}$ \\
\hline CAPEX & $\begin{array}{l}-10.79 \\
(7.664)\end{array}$ & $\begin{array}{c}15.56 \\
(11.56)\end{array}$ & $\begin{array}{c}-22.35^{* *} \\
(11.18)\end{array}$ \\
\hline LEV & $\begin{array}{c}1.892 \\
(2.701)\end{array}$ & $\begin{array}{c}-8.723 * * * \\
(2.187)\end{array}$ & $\begin{array}{l}-0.837 \\
(2.613)\end{array}$ \\
\hline LIQ & $\begin{array}{c}2.347 \\
(5.438)\end{array}$ & $\begin{array}{l}-1.246 \\
(5.276)\end{array}$ & $\begin{array}{c}2.673 \\
(5.930)\end{array}$ \\
\hline SIZE & $\begin{array}{c}4.232 * * * \\
(0.260)\end{array}$ & $\begin{array}{c}6.192 * * * \\
(0.412)\end{array}$ & $\begin{array}{c}5.574 * * * \\
(0.329)\end{array}$ \\
\hline $\mathrm{KOF}$ & $\begin{array}{c}0.637 * * * \\
(0.130)\end{array}$ & $\begin{array}{c}0.691 * * * \\
(0.164)\end{array}$ & $\begin{array}{c}0.239 \\
(0.166)\end{array}$ \\
\hline GDP PC & $\begin{array}{c}-.0003 * * * \\
(.00002)\end{array}$ & $\begin{array}{c}-.0002 * * * \\
(.00005)\end{array}$ & $\begin{array}{c}-.0003 * * * \\
(.00002)\end{array}$ \\
\hline GOV EFF & $\begin{array}{c}2.933 * * \\
(1.322)\end{array}$ & $\begin{array}{c}6.235^{* * * *} \\
(1.906)\end{array}$ & $\begin{array}{c}4.421 * * \\
(1.919)\end{array}$ \\
\hline POLCON & $\begin{array}{c}-21.95^{* * *} \\
(2.519)\end{array}$ & $\begin{array}{c}-14.19 * * * \\
(2.497)\end{array}$ & $\begin{array}{c}-15.71 * * * \\
(2.322)\end{array}$ \\
\hline ECO FREE & $\begin{array}{c}0.143 \\
(0.111)\end{array}$ & $\begin{array}{l}-0.145 \\
(0.143)\end{array}$ & $\begin{array}{l}0.0247 \\
(0.106)\end{array}$ \\
\hline INVEST PROT & $\begin{array}{c}-0.500^{*} \\
(0.259)\end{array}$ & $\begin{array}{c}0.340 \\
(0.352)\end{array}$ & $\begin{array}{c}0.160 \\
(0.318)\end{array}$ \\
\hline CONTR CORR & $\begin{array}{c}4.168 * * \\
(1.678)\end{array}$ & $\begin{array}{c}3.465 \\
(2.113)\end{array}$ & $\begin{array}{c}7.576^{* * *} \\
(1.613)\end{array}$ \\
\hline Constant & $\begin{array}{l}-15.19 \\
(14.40)\end{array}$ & $\begin{array}{c}-60.28 * * * \\
(18.08)\end{array}$ & $\begin{array}{l}-8.263 \\
(16.03)\end{array}$ \\
\hline Sargan's p & 0.45 & 1.00 & 1.00 \\
\hline Hansen's j & 0.14 & 0.57 & 0.17 \\
\hline Cragg Donald F-Statistic & $165.50 * * *$ & $165.50 * * *$ & $165.50 * * *$ \\
\hline Industry fe & yes & yes & yes \\
\hline Year fe & yes & yes & yes \\
\hline Observations & 1,434 & 1,434 & 1,434 \\
\hline R-squared & 0.185 & 0.221 & 0.205 \\
\hline
\end{tabular}

$\mathrm{N}=1,434$ firm-year observations. Clustered standard errors at firm level are reported in parentheses. Significance levels: *p $<$ $0.10 . * * \mathrm{p}<0.05 . * * * \mathrm{p}<0.0$ 
Table 4: Alternative second-stage IV GMM of ETRs and CSR, ENV and SOC

\begin{tabular}{|c|c|c|c|}
\hline & $\begin{array}{c}(1) \\
\text { CSR } \\
\end{array}$ & $\begin{array}{c}\text { (2) } \\
\text { ENV }\end{array}$ & $\begin{array}{c}(3) \\
\text { SOC }\end{array}$ \\
\hline EATR & $\begin{array}{c}-0.721 * * * \\
(0.090)\end{array}$ & $\begin{array}{c}-0.475 * * * \\
(0.104)\end{array}$ & $\begin{array}{c}-0.609 * * * \\
(0.057)\end{array}$ \\
\hline CAPEX & $\begin{array}{l}-9.054 \\
(8.216)\end{array}$ & $\begin{array}{c}13.78 \\
(13.44)\end{array}$ & $\begin{array}{c}-26.31 * * \\
(11.65)\end{array}$ \\
\hline LIQ & $\begin{array}{l}11.19 * \\
(5.801)\end{array}$ & $\begin{array}{c}-3.188 \\
(7.371)\end{array}$ & $\begin{array}{l}-0.467 \\
(5.635)\end{array}$ \\
\hline ROA & $\begin{array}{l}-4.234 \\
(5.623)\end{array}$ & $\begin{array}{l}-10.35 \\
(7.151)\end{array}$ & $\begin{array}{c}14.81 * * \\
(5.795)\end{array}$ \\
\hline LEV & $\begin{array}{c}3.765 \\
(2.673)\end{array}$ & $\begin{array}{c}-9.131 * * * \\
(2.908)\end{array}$ & $\begin{array}{c}0.543 \\
(2.719)\end{array}$ \\
\hline SIZE & $\begin{array}{c}5.026 * * * \\
(0.309)\end{array}$ & $\begin{array}{c}5.827 * * * \\
(0.465)\end{array}$ & $\begin{array}{c}5.370 * * * \\
(0.300)\end{array}$ \\
\hline $\mathrm{KOF}$ & $\begin{array}{c}0.752 * * * \\
(0.163)\end{array}$ & $\begin{array}{c}0.844 * * * \\
(0.199)\end{array}$ & $\begin{array}{c}0.529 * * * \\
(0.166)\end{array}$ \\
\hline GDP PC & $\begin{array}{c}-.0003 * * * \\
(.00005)\end{array}$ & $\begin{array}{c}-.0003 * * * \\
(.00005)\end{array}$ & $\begin{array}{c}-.0004 * * * \\
(.0003)\end{array}$ \\
\hline GOV EFF & $\begin{array}{c}3.557 * * \\
(1.492)\end{array}$ & $\begin{array}{c}6.733 * * * \\
(2.033)\end{array}$ & $\begin{array}{c}3.611 \\
(2.209)\end{array}$ \\
\hline POLCON & $\begin{array}{c}-16.68 * * * \\
(3.591)\end{array}$ & $\begin{array}{c}-10.44 * * \\
(4.821)\end{array}$ & $\begin{array}{c}-14.11 * * * \\
(3.520)\end{array}$ \\
\hline ECO FREE & $\begin{array}{l}0.0691 \\
(0.119)\end{array}$ & $\begin{array}{c}-0.0396 \\
(0.159)\end{array}$ & $\begin{array}{c}0.127 \\
(0.124)\end{array}$ \\
\hline INVEST PROT & $\begin{array}{l}0.547 * \\
(0.310)\end{array}$ & $\begin{array}{c}-0.970 * * \\
(0.389)\end{array}$ & $\begin{array}{c}-1.378 * * * \\
(0.256)\end{array}$ \\
\hline CONTR CORR & $\begin{array}{c}6.253 * * * \\
(1.812)\end{array}$ & $\begin{array}{c}0.687 \\
(2.217)\end{array}$ & $\begin{array}{c}6.094 * * * \\
(1.812)\end{array}$ \\
\hline Constant & $\begin{array}{c}-36.49 * * \\
(15.07)\end{array}$ & $\begin{array}{c}-50.25 * * \\
(19.68)\end{array}$ & $\begin{array}{l}-5.623 \\
(15.72)\end{array}$ \\
\hline Sargan's P & 0.84 & 0.83 & 0.83 \\
\hline Hansen's J & 0.11 & 0.53 & 0.19 \\
\hline Industry fe & Yes & Yes & Yes \\
\hline Year fe & Yes & Yes & Yes \\
\hline Clustering firm & Yes & Yes & Yes \\
\hline $\mathrm{R}$-squared & 0.194 & 0.221 & 0.206 \\
\hline
\end{tabular}

$\mathrm{N}=1,434$ firm-year observations. Clustered standard errors at firm level are reported in parentheses. Significance levels: ${ }^{*} \mathrm{p}<$ $0.10 . * * \mathrm{p}<0.05 . * * * \mathrm{p}<0.0$ 
Table 5: Fixed effect regression results of EATRs, CSR, ENV and SOC score

\begin{tabular}{|c|c|c|c|}
\hline & $\begin{array}{c}(1) \\
\text { CSR } \\
\end{array}$ & $\begin{array}{c}(2) \\
\text { ENV }\end{array}$ & $\begin{array}{c}(3) \\
\mathrm{SOC} \\
\end{array}$ \\
\hline EATR & $\begin{array}{c}-0.697 * * * \\
(0.164)\end{array}$ & $\begin{array}{c}-0.891 * * * \\
(0.212)\end{array}$ & $\begin{array}{c}-0.742 * * * \\
(0.181)\end{array}$ \\
\hline ROA & $\begin{array}{c}5.553 \\
(8.404)\end{array}$ & $\begin{array}{c}2.467 \\
(12.16)\end{array}$ & $\begin{array}{c}8.027 \\
(8.459)\end{array}$ \\
\hline CAPEX & $\begin{array}{l}-3.627 \\
(9.269)\end{array}$ & $\begin{array}{c}4.466 \\
(11.97)\end{array}$ & $\begin{array}{c}12.91 \\
(12.24)\end{array}$ \\
\hline LEV & $\begin{array}{c}2.626 \\
(5.375)\end{array}$ & $\begin{array}{c}6.918 \\
(7.320)\end{array}$ & $\begin{array}{c}1.161 \\
(5.893)\end{array}$ \\
\hline LIQ & $\begin{array}{l}-5.095 \\
(6.053)\end{array}$ & $\begin{array}{l}-11.81 \\
(10.32)\end{array}$ & $\begin{array}{l}-4.781 \\
(7.419)\end{array}$ \\
\hline SIZE & $\begin{array}{c}7.063 * * * \\
(1.392)\end{array}$ & $\begin{array}{c}7.954 * * * \\
(2.247)\end{array}$ & $\begin{array}{c}5.830 * * * \\
(1.488)\end{array}$ \\
\hline $\mathrm{KOF}$ & $\begin{array}{l}-0.345 \\
(0.434)\end{array}$ & $\begin{array}{l}-0.337 \\
(0.609)\end{array}$ & $\begin{array}{l}-0.319 \\
(0.447)\end{array}$ \\
\hline GDP PC & $\begin{array}{c}-0.0002 * * * \\
(.00005)\end{array}$ & $\begin{array}{c}-0.0003 * * * \\
(.00008)\end{array}$ & $\begin{array}{c}-0.0002 * * * \\
(.00007)\end{array}$ \\
\hline GOV EFF & $\begin{array}{l}4.664 * \\
(2.583)\end{array}$ & $\begin{array}{c}3.921 \\
(3.032)\end{array}$ & $\begin{array}{c}4.413 \\
(2.929)\end{array}$ \\
\hline POLCON & $\begin{array}{c}-20.21 * * * \\
(3.801)\end{array}$ & $\begin{array}{c}-14.73 * * * \\
(3.613)\end{array}$ & $\begin{array}{c}-13.37 * * * \\
(3.953)\end{array}$ \\
\hline ECO FREE & $\begin{array}{l}-0.240 \\
(0.180)\end{array}$ & $\begin{array}{l}0.0337 \\
(0.242)\end{array}$ & $\begin{array}{l}-0.214 \\
(0.229)\end{array}$ \\
\hline INVEST PROT & $\begin{array}{c}1.320 * * * \\
(0.420)\end{array}$ & $\begin{array}{c}1.560 * * * \\
(0.493)\end{array}$ & $\begin{array}{c}1.442 * * * \\
(0.459)\end{array}$ \\
\hline CONTR CORR & $\begin{array}{c}2.583 \\
(3.296)\end{array}$ & $\begin{array}{l}-0.520 \\
(3.544)\end{array}$ & $\begin{array}{c}4.285 \\
(3.767)\end{array}$ \\
\hline Constant & $\begin{array}{c}19.67 \\
(46.72)\end{array}$ & $\begin{array}{c}11.25 \\
(71.18)\end{array}$ & $\begin{array}{c}39.78 \\
(47.41)\end{array}$ \\
\hline $\begin{array}{l}\text { Industry fe } \\
\text { Country fe } \\
\text { Firm fe } \\
\text { Clustering firm } \\
\text { R-squared } \\
\end{array}$ & $\begin{array}{l}\text { Yes } \\
\text { Yes } \\
\text { Yes } \\
\text { Yes } \\
0.67 \\
\end{array}$ & $\begin{array}{l}\text { Yes } \\
\text { Yes } \\
\text { Yes } \\
\text { Yes } \\
0.63 \\
\end{array}$ & $\begin{array}{l}\text { Yes } \\
\text { Yes } \\
\text { Yes } \\
\text { Yes } \\
0.61 \\
\end{array}$ \\
\hline
\end{tabular}

$\mathrm{N}=1,434$ firm-year observations. Clustered standard errors at firm level are reported in parentheses. Significance levels: * $<$

$$
0.10 . * * \mathrm{p}<0.05 . * * * \mathrm{p}<0.0
$$




\section{Appendix}

\section{A1 Variables description}

\begin{tabular}{|c|c|c|c|}
\hline Variables & Measures & Description & Data sources \\
\hline Corporate Social Responsibility score & CSR & $\begin{array}{l}\text { Thomson Reuters ESG Score is an overall } \\
\text { company score based on the self-reported } \\
\text { information in the environmental, social and } \\
\text { corporate governance pillars. }\end{array}$ & $\begin{array}{l}\text { Thomson Reuters } \\
\text { ASSET4 }\end{array}$ \\
\hline Environmental score & ENV & $\begin{array}{c}\text { Thomson Reuters Environmental Score is based } \\
\text { on a weighted average of Resource use score, } \\
\text { Emission score and Environmental innovation } \\
\text { score }\end{array}$ & $\begin{array}{l}\text { Thomson Reuters } \\
\text { ASSET4 }\end{array}$ \\
\hline Social score & SOC & $\begin{array}{c}\text { Thomson Reuters social Score is based on a } \\
\text { weigthed average of } \\
\text { Workforce score, Human rights score, } \\
\text { Community score and Product responsibility } \\
\text { score }\end{array}$ & $\begin{array}{l}\text { Thomson Reuters } \\
\text { ASSET4 }\end{array}$ \\
\hline Effective Average tax rate & EATR & $\begin{array}{c}\text { Country Average corporate tax rate weighted on } \\
\text { the firm's specific debt to equity ratio and } \\
\text { industry }\end{array}$ & $\begin{array}{l}\text { Own estimations on the } \\
\text { basis of Spengel, et. al. } \\
\text { (2018) data }\end{array}$ \\
\hline Return on Asset & ROA & $\begin{array}{l}\text { Measured as the pre-tax income, scaled by the } \\
\text { total of asset }\end{array}$ & $\begin{array}{l}\text { Own estimation based on } \\
\text { Thomson Reuters } \\
\text { ASSET4 database }\end{array}$ \\
\hline Liquidity & LIQ & $\begin{array}{c}\text { Measured as the total cash scaled by the total of } \\
\text { asset }\end{array}$ & $\begin{array}{l}\text { Thomson Reuters } \\
\text { Datastream }\end{array}$ \\
\hline Size of firm & SIZE & Measured as the natural logarithm of total asset & $\begin{array}{l}\text { Own estimation based on } \\
\text { Thomson Reuters } \\
\text { Datastream measures }\end{array}$ \\
\hline Leverage & LEV & Measured as the total debt to total asset ratio & $\begin{array}{l}\text { Own estimation based on } \\
\text { Thomson Reuters } \\
\text { Datastream measures }\end{array}$ \\
\hline Capital expenditure & CAPEX & $\begin{array}{l}\text { Measured as the capital expenditure to total asset } \\
\text { ratio }\end{array}$ & $\begin{array}{l}\text { Own estimation based on } \\
\text { Thomson Reuters } \\
\text { Datastream measures }\end{array}$ \\
\hline GDP pro capita & GDP PC & $\begin{array}{l}\text { Measured as the total amount of country GDP pro } \\
\text { capita }\end{array}$ & IMF Database \\
\hline
\end{tabular}




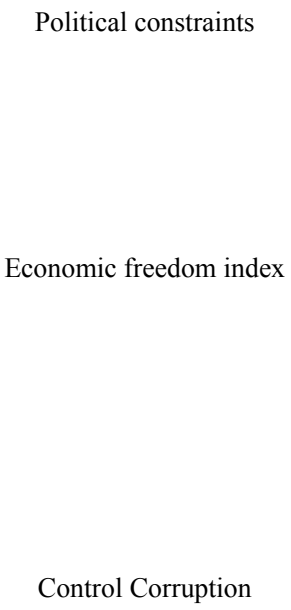

POLCON

ECO FREE

\section{CONTR CORR}

GOV EFF

KOF

INVEST PROT
Is a Country index provided to identify underlying political structures and measure their ability to develop credible policy commitments

Is a Country index that capture the degree of country economic freedom

Is a Worldwide Governance indicator, that capture the perceptions of the extent to which public power is exercised for private gain, including both petty and grand forms of corruption
Wharton University of Pennsylvania

World Bank

World Bank

World Bank

The Government Effectiveness index captures perceptions of the quality of public services, the quality of the civil service and the degree of its independence from political pressures, the quality of policy formulation and implementation, and the credibility of the government's commitment to

$$
\text { such policies }
$$

Is a Country index that capture the rate of globalization in Countries around the world

Swiss economic Institute ETH Zurich 


\begin{tabular}{|c|c|c|c|c|c|}
\hline & $\begin{array}{c}(1) \\
\text { First stage } \\
\text { EATR } \\
\end{array}$ & $\begin{array}{c}(2) \\
\text { First stage } \\
\text { ROA }\end{array}$ & $\begin{array}{c}(3) \\
\text { First stage } \\
\text { CAPEX }\end{array}$ & $\begin{array}{c}\text { (4) } \\
\text { First stage } \\
\text { LEV }\end{array}$ & $\begin{array}{c}(5) \\
\text { First stage } \\
\text { LIQ }\end{array}$ \\
\hline EATR t-1 & $\begin{array}{c}0.853 * * * \\
(0.0138)\end{array}$ & & & & \\
\hline Industry peer ROA & & $\begin{array}{c}0.994 * * * \\
(0.013)\end{array}$ & & & \\
\hline Industry peer CAPEX & & & $\begin{array}{c}0.987 * * * \\
(0.0199)\end{array}$ & & \\
\hline Industry peer LEV & & & & $\begin{array}{l}1.001 * * * \\
(0.0164)\end{array}$ & \\
\hline Industry peer LIQ & & & & & $\begin{array}{c}0.997 * * * \\
(0.0132)\end{array}$ \\
\hline Constant & $\begin{array}{c}-4.777 * * \\
(2.224)\end{array}$ & $\begin{array}{c}0.0383 \\
(0.0352)\end{array}$ & $\begin{array}{c}0.0321 \\
(0.0260)\end{array}$ & $\begin{array}{c}-0.0695 \\
(0.0892)\end{array}$ & $\begin{array}{c}0.0252 \\
(0.0411)\end{array}$ \\
\hline Industry fe & Yes & Yes & Yes & Yes & Yes \\
\hline Year fe & Yes & Yes & Yes & Yes & Yes \\
\hline Controls & Yes & Yes & Yes & Yes & Yes \\
\hline Cragg-Donald first stage $f$ & $165.50 * * *$ & $117.77 * * *$ & $65.85 * * *$ & $107.62 * * *$ & $88.64 * * *$ \\
\hline Observations & 1,465 & 1,495 & 1,497 & 1,501 & 1,495 \\
\hline R-squared & 0.934 & 0.911 & 0.851 & 0.903 & 0.885 \\
\hline
\end{tabular}

A2 OLS first-stage result of goodness of instruments 